\title{
Wet Dream
}

National Cancer Institute

\section{Source}

National Cancer Institute. Wet Dream. NCI Thesaurus. Code C86938.

An involuntary ejaculation of semen accompanying an erotic dream. 